Journal, which did so much to maintain standards and morale at home, to hold and strengthen links with museum men overseas, and to build soundly based plans for museums in the post-War world. It is good that he is to continue to serve his chosen profession as curator of the museum of the Torquay Natural History Society.

Mr. Alan Warhurst

Mr. Alan Warhurst, who succeeds Dr. F. S. Wallis as director of the Bristol Museums, was educated at the Canon Slade Grammar School, Bolion, and the University of Manchester, where he secured honours in history, specializing in the Roman occupation of Britain. $\mathrm{He}$ is particularly interested in medieval archæology in its broadest sense and has undertaken field-research in Chester, Kent and Northamptonshire, having published a number of valuable papers. During the War he saw service in India, being commissioned to the Lancashire Fusiliers. His museum service began at the Grosvenor Museum, Chester, then extended to the Maidstone Museum and Art Gallery, where he was deputy curator, and in 1955 to the Northampton Museum and Art Gallery, to which he was promoted curator. There he started a major reorganization scheme and, having completed with notable success the archrological gallery, he was about to commence the boot and shoe gallery.

\section{U.S. Scientific Attaché in India: Prof. E. C. Watson}

Prow. E. C. Watson, dean of the faculty for the past fourteen years at the California Institute of Technology, is retiring to become scientific attaché to the U.S. Embassy in India. Dr. Watson adminis tered the Institute's rocket development programme during the second World War after having managed in the earlier days the Institute's physics laboratories. He has won national recognition for his studies in the history of seience and for his remarkable collection of manuscripts, pictures and prints on the subject. He has published nearly eighty articles in the American Journal of Physics depicting the history of physics. This is in addition to numerous scientific papers and a book entitled "Mechanics, Molecular Physies, Heat and Sound". His main research has been in the field of $\mathrm{X}$-ray photo electrons.

\section{National Science Foundation : Dr. Bowen C. Dees}

Dr. Bowen C. Dees has been appointed assistant director for scientific personnel and education at the U.S. National Science Foundation. Prior to going to the Foundation in 1951, Dr. Dees served as division chief and physicist with the Scientific and Technical Division of the General Headquarters of the Supreme Commander for the Allied. Powers in Tokyo during 1947-51. He had previously lectured on physics at New York University, Mississippi College, the Massachusetts Institute of Technology and Rensselaer Polytechnic Institute. Dr. Dees received his A.B. from Mississippi College in 1937 and his $\mathrm{Ph} . \mathrm{D}$. from New York University in 1942.

\section{Nomenclature in Titrimetric Analysis}

During the Twentieth Conference of the International Union of Pure and Applied Chemistry, held in Munich in August 1959, the Committee of the Analytical Chemistry Section discussed certain points of confusion in the literature. Referring to the notation of indicators in titrimetric analysis, it was pointed out that many dyestuffs recommended as indi- cators in chelatometric and redox titrations have been given various trivial names. Examples can be found in the literature of a compound being recommended as a new indicator when the compound has in fact been in use for years under a different name. To avoid future confusion, the Committee recommends that when a dyestuff is proposed as an indicator in any type of titration, and particularly when it is claimed as new, the British Colour Index or Schult\% Number be quoted in addition to the trivial name. As regards the terminology of complexing agents used as titrants, it is recommended that: $(a)$ the group of polyamino-polycarboxylic acids which form anionic complexes shall be termed 'complexans'; $(b)$ titration processes in which any type of complexing titrant is used shall be termed 'complexometric titrations' ; $(c)$ those complexometric titrations which involve titration with a chelating agent shall be termed 'chelatometric titrations' and represent ab special type of complexometric titration.

\section{Research Vessel for Woods Hole Oceanographic Institution}

A NEw research vessel will be provided for studies in oceanography by a grant of $3,000,000$ dollars from the National Science Foundation to the Woods Hole Oceanographic Institution. The new vessel will replace the research vessel Atlantis, the twenty-eightyear-old 'flagship' of the Institution's fleet. Because of the probability that the National Science Foundation would be asked to support the construction of research vessels, it made a grant to Woods Hole in 1958 to study capabilities and preliminary designs of various sizes and types of such vessels. This study, in turn, benefited from earlier studies made by the Institution with funds provided by the Office of Naval Research. The vessel will have an overall length of $175 \mathrm{ft}$., beam of $36 \mathrm{ft}$., and loaded displacement of 1,040 tons. She will have an operating range of 7,500 miles at a cruising speed of 12 knots. Incorporated in the design are roll- and piteh-damping devices, wide speed control and high degree of manœuvrability, superior laboratory spaces, and excellent working facilities. Preliminary design plans were prepared for the Institution by $\mathbf{M}$. Rosenblatt and Son, of New York. Additional features which have been considered for possible inclusion in the detailed plans and specifications include anti-rolling tanks, acoustical 'quietness' for studying underwater sound characteristics, a gravity laboratory, an aquarium, and ample freezer space for preserving bottom-sediment cores and biological specimens. The total complement of the ship will be 37 , of whom 19 will be scientists.

\section{Radiocarbon Dating}

THE appearance of Radiocarbon Supplement Vol. 1 of the American Journal of Science marks an important step forward in the publication of radiocarbon dates. In the past, date lists have appeared at irregular. intervals in a number of journals, making it difficult for potential users of the dates to keep themselves fully informed of all the work in this field. The dating laboratories have been well aware of this problem, but there are considerable difficulties in attempting to use any one of the existing scientific journals with a wide circulation. For this reason, the editors of the American Journal of Science are to be commended on this project, which provides a single, relatively inexpensive, annual publication spocifically for radiocarbon dates and associated measurements. 